Kaganga : Jurnal Pendidikan Sejarah dan Riset Sosial Humaniora

Volume 2, Nomor 1, Juni 2019

e-ISSN : 2598-4934

$p-I S S N$ : 2621-119X

DOI : https://doi.org/10.31539/kaganga.v2i1.707

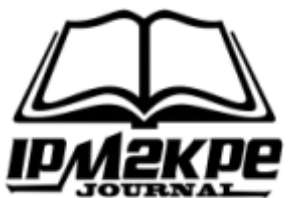

\title{
PERAN MUSEUM DALAM PEMBELAJARAN SEJARAH
}

\author{
Dedi Asmara \\ STKIP Yayasan Abdi Pendidikan Payakumbuh \\ dedi2019@gmail.com
}

\begin{abstract}
ABSTRAK
Penelitian ini bertujuan untuk mengetahui bagaimana peran museum dalam pembelajaran sejarah. Metode yang digunakan dalam penelitian ini adalah penelitian kualitatif untuk memahami fenomena tentang apa yang dialami subyek penelitian. Hasil penelitian didapatkan bahwa dengan bergesernya paradigma museum dari koleksi (collection oriented) ke pengunjung (visitor oriented), maka masyarakat luas mempunyai akses lebih banyak terhadap koleksi museum. Museum harus menyediakan berbagai akses bagi pengunjung agar mereka dapat memperoleh kesempatan menggunakan fasilitas dan layanan, riset dan studi koleksi, sajian display, termasuk konsultasi dangan staf museum. Simpulan dari penelitian ini adalah Keberadaan musem dalam dunia pendidikan begitu dibutuhkan, termasuk dalam pembelajaran sejarah. Baik dari level pendidikan yang peling rendah hingga tinggi. Seorang siswa dari sekolah dasar akan senang bila belajar di museum, dibandingkan di dalam kelas. Di museum mereka bisa mengamati benda peninggalan masa lampau secara langsung. Proses pembelajaran juga bisa dilaksanakan oleh pengunjung yang bukan berasal dari kalangan pendidikan. Seorang turis yang berkunjung ke museum, baginya akan menambah khasanah kekayaan mental dan intelektual untuk mengetahui masa lampau dari suatu etnis atau kelompok masyarakat. Di museum juga bisa dilaksanakan penelitian koleksi, hal ini memberikan peluang untuk menghasilkan temuan terbaru.Penelitian bagi mahasiswa, dosen, dan siapapun yang tertarik dengan museum
\end{abstract}

Kata kunci: Museum, Belajar, Pengunjung.

\begin{abstract}
This study aims to find out how the role of the museum in learning history. The method used in this study is qualitative research to understand the phenomenon of what is experienced by research subjects. The results showed that with the shift of the museum paradigm from collection (collection oriented) to visitors (visitor oriented), the wider community had more access to museum collections. The museum must provide various access for visitors so that they can get the opportunity to use facilities and services, research and study collections, display offerings, including consultations with museum staff. The conclusions of this study are that the existence of museums in the world of education is so needed, including in history learning. Both from the low to high education level. A student from elementary school will be happy when studying in a museum, compared to in the classroom. In the museum they can observe ancient relics directly. The learning process can also be carried out by
\end{abstract}


visitors who are not from the education community. A tourist visiting the museum, for him will add to the repertoire of mental and intellectual wealth to know the past from an ethnic or community group. In the museum, collection research can also be carried out, this provides an opportunity to produce the latest findings. Research for students, lecturers, and anyone interested in the museum

Keywords: Museums, Learning, Visitors.

\section{PENDAHULUAN}

Dibandingkan negara-negara yang ada di Asia Tenggara, sejarah permuseuman di Indonesia jauh lebih awal kehadirannya. Pada tanggal 24 April 1778, di nusantara telah didirikan Bataviaaschap Genootschap van Kusten en Wetenschaapen yang merupakan cikal bakal museum sesuai dengan slogan Ten Nutte van het Gemeen atau untuk kepentingan umum. Setelah masa kemerdekaan, namanya diganti dengan Lembaga Kebudayaan Indonesia pada tahun 1950.Pada periode berikutnya museum warisan Belanda itu diubah menjadi Museum Pusat (1962), dan kemudian menjadi Museum Nasional pada tahun 1970.

Berdasarkan catatan sejarah, sebenarnya pada tahun 1662 Indonesia pernah memiliki museum yang didirikan oleh Rumphios di Ambon, yaitu De Amboinsch Raritenkaimer. Sayangnya museum yang tertua di nusantara itu lenyap ditelan waktu seiring perginya sang pendiri. Penting juga untuk diketahui bahwa ada beberapa museum yang berdiri sebelum kemerdekaan RI yaitu:Museum Radyapustaka (1890), Museum Zoologi Bogor (1894), Museum Rumah Adat Aceh (1915), Museum Purbakala Trowulan (1820), Museum Geologi Bandung (1929), Museum Bali (1932), Museum Rumah Adat Baanjuang Bukittinggi (1933), Museum Sonobudoyo (1935), Museum
Simalungun (1938) dan Museum Herbarium Bogor (1941).

Pada tahun 1948, Pemerintah RI mendirikan Jawatan Kebudayaan di Yogjakarta. Jawatan ini bertugas untuk menggali, membina, dan mengembangkan kebudayaan bangsa dalam struktur organisasinya berada dalam Kementerian Pendidikan, Pengajaran, dan Kebudayaan. Jawatan ini didirikan dengan maksud untuk menangkal masuknya pengaruh negatif ke Indonesia.Pada tahun 1957, jawatan ini memiliki satu unit kerja yang bernama Urusan Museum.Urusan Museum ini pada tahun 1965 ditingkatkan lagi menjadi Lembaga Museum-Museum Nasional.Pada tahun 1986, Lembaga Museum-Museum Nasional itu dijadikan Direktorat Museum dalam lingkungan Direktorat Jenderal Kebudayaan pada masa Kabinet Ampera.Tahun 1975 , Direktorat Museum disempurnakan menjadi Direktorat Permuseuman.

Pada tahun 2000, Direktorat Permuseuman diubah menjadi Direktorat Sejarah dan Museum dibawah Departemen Pendidikan Nasional.Pada tahun 2001 Direktorat Sejarah dan Museum diubah lagi menjadi Direktorat Permuseuman. Pada tahun 2002, susunan organisasi diubah menjadi Direktorat Purbakala dan Permuseuman dibawah Badan Pengembangan Kebudayaan dan Pariwisata.Tahun 2004 Direktorat 
Purbakala dan Permuseuman diubah lagi menjadi Asdep Purbakala dan Permuseuman. Tahun 2005 dibentuk kembali Direktorat Museum dibawah Direktorat Jenderal Sejarah dan Purbakala, Departemen Kebudayaan dan Pariwisata.

Dalam rangka pembinaan dan pengembangan permuseuman di Indonesia, pada tahun 1971 Direktorat Museum mengelompokkan museum menjadi tiga jenis yaitu Museum Umum, Museum khusus, dan Museum Lokal. Kemudian pengelompokkan ini diubah pada tahun 1975 menjadi museum umum, museum khusus, dan museum pendidikan. Pada tahun 1980, pengelompokkan museum disederhanakan menjadi musuem umum dan museum khusus. Museum umum dan museum khusus itu didasarkan pada tingkatan dan kedudukannya dijabarkan menjadi Museum Tingkat nasional, museum tingkat regional (provinsi), dan museum tingkat lokal (kotamadya/ kabupaten).

Patut disyukuri bahwa perhatian pemerintah terhadap bidang permuseuman cukup baik. Dengan dimulainya proyek rehabilitasi dan perluasan museum pusat dan Bali (REPELITA I). Proyek permuseuman ini berkembang menjadi proyek pengembangan dan pembinaan permuseuman di Indonesia. Memasuki REPELITA II, ditetapkan suatu kebijakan untuk memugar dan memperluas museum-museum daerah. Warisan zaman kolonial diarahkan menjadi jenis museum umum, dan bagi provinsi yang belum memiliki museum, didirikan museum baru dengan jenis museum umum. Melalui Direktorat Permuseuman pemerintah tidak hanya memperhatikan, membina dan mengembangkan museum-museum dilingkungan Departemen Pendidikan dan Kebudayaan, melainkan juga museum yang dikelola oleh departemen lain, swasta, dan pemerintah daerah.Sejak PELITA I sampai PELITA V (25 tahun), pembangunan permuseuman telah berkembang dan jumlah museum di Indonesia tercatat 262 buah.Museum tersebut terdiri atas museum-museum dilingkungan Depatemen Pendidikan dan Kebudayaan, museum swasta, dan museum Pemerintah Daerah.

Dalam konteks museum pada tataran internasional, gagasan pokok untuk mendirikan museum umum disetiap Ibukota Provinsi itu ialah agar dapat mencerminkan falsafah umum museum sebagaimana tersirat dalam rumusan International Council of Museums (ICOM). Pada tataran nasional dikenal arah dan tujuan yang jelas untuk apa museum didirikan, yaitu sebagai sarana edukatif-kultural, inspiratif, dan rekreatif dalam rangka menunjang usaha pemerintah mencerdaskan kehidupan bangsa dan memajukan kebudayaaan nasional. Oleh karena itu, dunia permuseuman Indonesia mempunyai landasan kebijakan, yaitu Pancasila, UUD 1945, GBHN (sebelum reformasi).Dengan demikian, dunia permuseuman Indonesia sebenarnya telah menetapkan tiga pilar utama yang dijadikan kebijakan dalam rangka kegiatan operasional museum, yaitu: mencerdaskan bangsa, kepribadian bangsa, dan ketahananan nasional dan wawasan nusantara. Jelas bahwa keberadaan museum itu bukan suatu lembaga pelengkap belaka agar bangsa Indonesia tampak berbudaya. Museum yang baik akan menyebarkan falsafah 
yang dianut bangsanya. Museum Indonesia, tentunya juga berasaskan Pancasila serta menghormati dinamika perkembangan masyarakatnya.

\section{METODE PENELITIAN}

Metode penelitian yang digunakan pada tulisan ini adalah metode kualittatif. Menurut Moleong (2006), Metode Kualitatif adalah penelitian yang bermaksud untuk memahami fenomena tentang apa yang dialami oleh subyek penelitian. Misalnya perilaku, persepsi, motivasi, tindakan, dan lain sebagainya secara holistik dengan cara deskriptif dalam bentuk kata-kata dan bahasa pada suatu konteks khusus yang alamiah dan dengan memanfaatkan berbagai metode alamiah. Penelitian ini dilaksanakan untuk memahami dan mendeskripsikan secara sistematis, faktual, dan akurat mengenai suatu fakta, sifat, dan hubungan yang muncul dalam peran museum dalam pembelajaran sejarah.

Subyek penelitian merupakan orang-orang yang dianggap mampu memberikan informasi mengenai latar belakang dan keadaan yang sebenarnya dari objek yang diteliti sehingga data yang dihasilkan dapat akurat.Pihakpihak yang dipilih menjadi subyek penelitian adalah Pengelola Museum, Pengunjung, dan pihak terkait yang berkaitan langsung dengan museum yang menjadi sumber data primer. Selain data primer juga ada data sekunder yang diolah dari buku, majalah, jurnal, surat kabar yang berkaitan dengan museum dan pembelajaran sejarah.

Teknik pengumpulan data untuk mendapatkan data yang valid dan akurat, dilakukan beberapa hal:

\section{Wawancara}

Teknik wawancara pada penelitian ini bersifat semi terstruktur, dimana dalam wawancara menggunakan pertanyaan terbuka, namun ada batasan tema dan alur pembicaraan serta ada pedoman wawancara yang digunakan sebagai kontrol dalam wawancara.

\section{Observasi}

Dalam penelitian ini menggunakan teknik obsevasi nonpartisan, dimana peneliti tidak terlibat dan hanya sebagai pengamat independen. Peneliti mengamati kegiatan pelayanan terhadap pengunjung museum. Observasi terstruktur dilakukan apabila peneliti telah tahu variabel yang akan diamati.

\section{Dokumentasi}

Usaha pendokumentasian yang dilakukan dalam penelitian ini untk mendapatkan data yang telah diolah baik dalam arsip tertulis maupun arsip lainnya

Setelah data dikumpulkan, tahap selanjutnya adalah teknik analisi data yaitu mengolah data dan menganalisi data. Data yang diperoleh dianalisis secara deskriptif yaitu dengan cara menghimpun fakta dan mendeskripsikannya. Analisis ini dilakukan pada seluruh data yang diperoleh dari hasil wawancara, obeservasi, dan dokumen. Menurut Mathew B. Miles dan A. Micheal Huberman dalam Rohidi (1992), mengatakan bahwa analisis kualitatif melalui empat tahap yaitu pengumpulan data, reduksi data, penyajian data, dan penarikan kesimpulan. Oleh Tjetjep Rohendi Rohidi disederhanakannya menjadi tiga tahap yaitu: 


\section{Reduksi Data}

Tahap ini diartikan sebagai proses pemilihan, pemusatan perhatian atau penyederhanaan, pengabstrakan dan transformasi kata dasar yang di dapat dari catatan di lapangan. Reduksi data berlangsung secara terus sesudah penelitian lapangan. Selain itu reduksi data merupakan bentuk analisis yang menajamkan, menggolongkan, mengarahkan, membuang yang tidak perlu, dan mengorganisasikan sehingga dapat ditarik kesimpulan.

\section{Penyajian data}

Penyajian data adalah upaya penyusunan sekumpulan informasi ke dalam suatu matriks atau konfigurasi yang mudah dipahami.Penyajian data ini dapat berupa naratif, matrik, grafik, dan bagian yang dirancang untuk menggabungkan informasi sehingga mencapai analisis kualitatif yang valid.

\section{Penarikan kesimpulan}

Penarikan kesimpulan merupakan simpulan dari data dan fakta. Pengumpulan data, penyajian data, dan penelitian dapat memberikan makna, tafsiran, argumen membandingkan data dan mencari hubungan antara satu komponen yang lain sehingga dapat ditarik kesimpulan.

\section{HASIL DAN PEMBAHASAN Sejarah Museum}

Museum berasal dari kata latin "Mouseion", yaitu kuil untuk sembilan dewa muze, anak-anak Dewa Zeus yang tugas utamanya adalah menghibur. Arti museum dapat dipahami dari kegiatannya. Fungsi museum dari zaman ke zaman terus mengalami perubahan sesuai dengan situasi dan kondisi, tetapi hakikatnya pengertian museum itu tidak berubah. Landasan ilmiah dan kesenian tetap menjiwai arti museum hingga kini. Pengertian museum menurut ICOM adalah sebuah lembaga yang bersifat tetap, tidak mencari keuntungan, melayani masyarakat dan perkembangannya, terbuka untuk umum, memperoleh, merawat, menghubungkan dan memamerkan untuk tujuan studi, pendidikan, dan kesenangan, barang pembuktian manusia dan lingkungannya.

Menurut Peraturan Pemerintah (PP) No. 19 Tahun 1995, museum adalah lembaga, tempat penyimpanan, perawatan, pengamanan, dan pemanfaatan benda bukti materil hasil budaya manusia, alam dan lingkungannya guna menunjang upaya perlindungan dan pelestarian kekayaan budaya bangsa. Berdasarkan PP ini museum memiliki tugas menyimpan, merawat, mengamankan, dan memanfaatkan koleksi museum benda cagar budaya. Dengan demikian, museum memiliki fungsi besar yaitu sebagai tempat pelestarian dan sumber informasi benda budaya dan alam.

Sebagai tempat pelestarian, museum harus melaksanakan kegiatan Penyimpanan, yang didalamnya meliputi kegiatan: (1) pengumpulan benda untuk menjadi koleksi melalui hibah, imbalan jasa, titipan atau hasil kegiatan lain sesuai ketentuan peraturan perundangaan yang berlaku; (2) Pencatatan koleksi ke dalam buku registrasi dan inventarisasi; (3) Sistem penomoran; (4) Penataan koleksi di dalam ruang pameran maupun di luar ruangan pameran dan ruangan gudang koleksi bagi koleksi pada kondisi tertentu.

Kegiatan Perawatan, meliputi kegiatan untuk mencegah dan menanggulangi kerusakan koleksi yang 
dilakukan oleh tenaga ahli. Perawatan tersebut dapat dilakukan baik didalam maupun diluar ruangan.Untuk mencegah kerusakan koleksi dapat dibuat duplikat agar koleksi tersebut tetap dapat dimanfaatkan sebagai sumber rinformasi.

Kegiatan Pengamanan, meliputi kegiatan perlindungan untuk menjaga koleksi dari gangguan atau kerusakan yang disebabkan oleh faktor alam dan ulah manusia. Untuk melakukan kegiatan pengamanan, pengelola museum melakukan beberapa upaya, diantaranya melengkapi sarana dan prasarana pengamanan, mengatur tata tertib pengunjung, dan menyediakan tenaga pengawas atau keamanan museum.

Sebagai sumber informasi, museum melaksanakan kegiatan pemanfaatan melalui penelitian dan penyajian. Penelitian dilakukan untuk pengembangan kebudayaan nasional, ilmu pengetahuan, teknologi dan seni yang dilakukan berdasarkan izin dari kepala museum yang bersangkutan. Hasil penelitian diserahkan kepada museum.Penelitian yang berakibat pada kerusakan koleksi haris didampingi petugas museum.

Penyajian di museum tetap memperhatikan aspek pelestarian dan pengamanannya melalui pameran, panduan keliling museum, bimbingan karya tulis, ceramah, pemutara slidel film/ video, dan museum keliling. Museum yang baik harus menjadi jendela yang dapat memberikan informasi tentang daerah bagi museum daerah, peristiwa bagi museum sejarah, dan ilmu bagi museum ilmu pengetahuan, teknologi dan seni sehingga museum dapat menjadi tempat yang bermanfaat bagi kecerdasan masyarakat yang berkunjung.

\section{Layanan Museum}

Metode penyajian di museum terdiri dari metode: Pendekatan Intelektual adalah cerita penyajian benda-benda koleksi museum yang mengungkapkan informasi tentang guna, arti, dan fungsi benda koleksi museum. Metode pendekatan romatik (evokatif) adalah cara penyajian bendabenda koleksi museum yang mengungkapkan suasana tertentu yang berhubungan dengan benda-benda yang dipamerkan. Metode pendekatan estetik adalah cara penyajian bendabenda koleksi museum yang mengungkapkan nilai artistik yang ada pada benda koleksi museum. Metode pendekatan simbolik adalah cara penyajian benda-benda koleksi museum dengan menggunakan simbol-simbol tertentu sebagai media interpretasi pengunjung. Metode pendekatan kontemplatif adalah cara penyajian koleksi di museum untuk membangun imajinasi pengunjung terhadap koleksi yang dipamerkan. Metode pendekatan interaktif adalah cara penyajian koleksi di museum dimana pengunjung dapat berinteraksi langsung dengan koleksi yang dipamerkan. Penyajian interaktif dapat menggunakan teknologi informasi.

Metode pameran diartikan sebagai sebuah komunikasi.Pada kategori ini, terdapat empat macam metode pameran yaitu penyajian objek, diorama, planetarium, dan eksplanasi.Metode pameran diartikan sebagai sebuah pengalaman. Pada kategori ini, terdapat enam metode pameran yang digunakan, yaitu: pengalaman melalui sentuhan (touch), pengalaman melalui memperlihatkan 
(showing), pengalaman melalui modelmodel bergerak (moving models), pengalaman melalui eksperimen yang saintifik (scientific experiment), dan pengalaman melalui gambar.

Setiap penyelenggaraan pameran penting untuk selalu diawasi dengan pengkajian/penelitian terhadap gagasan yang akan dituangkan dalam pameran. Disini peran kurator museum diperlukan untuk melakukan kajian dalam mewujudkan gagasan tersebut. Hal tersebut dapat dilakukan melalui evaluasi hasil pameran sebelumnya, diskusi dengann berbagai pihak yang relevan dengan gagasan pameran, survei terhadap pemahaman masyarakat, kajian pustaka sebelum disusun menjadi sebuah proposal yang menguraikan alur cerita, tema dan sub tema, serta informasi koleksi dalam label.

\section{Museum dan Pengunjung}

Dengan bergesernya paradigma museum dari koleksi (collection oriented) ke pengunjung (visitor oriented), maka studi pengunjung harus dilakukan oleh pengelola museum. Layanan pengunjung pada dasarnya harus dipusatkan pada bagaimana koordinasi antar staf museum dalam melayani pengunjung. Museum harus menyediakan berbagai akses bagi pengunjung agar mereka dapat memperoleh kesempatan menggunakan fasilitas dan layanan, riset dan studi koleksi, sajian display, termasuk konsultasi dangan staf museum (Olofsson, 1991).

Dalam memberikan layanan kepada pengunjung, penting untuk diperhatikan apa sesungguhnya harapan pengunjung. Harapan ini harus dipenuhi sehingga museum mendatangkan manfaat bagi pengunjung. Riset terhadap pengunjung dapat memberi gambaran bagaimana pola kunjungan, kebutuhan, dan sikap pengunjung.Hasil riset ini dapat digunakan sebagai pijakan museum dalam membuat perencanaan program museum di masa datang. Pendekatan kuantitatif dan kualitatif juga dapat digunakan dalam merancang riset pengunjung.

Kegiatan pelayanan pegunjung sebisanya juga mempertimbangkan tipe dan kebutuhan pengunjung. Kategori tipe pengunjung tipe individual, mereka adalah pengunjung yang memiliki alasan khusus, misalnya ingin melihat koleksi yang khusus, atau ingin melakukan riset khusus terhadap koleksi museum tertentu untuk memperoleh informasi yang detail. Tipe kelompok dewasa, biasanya banyak menghabiskan waktu di museum untuk berdiskusi secara santai. Tipe kelompok keluarga, biasanya memiliki kebutuhan yang besar baik dari segi usia maupun minat. Anak-anak mungkin kurang tertarik pada koleksi museum.Namun dengan kreatifitas tinggi yang dimiliki pengelola (misalnya permainan, kuis, display serta brosur yang menarik) maka anak-anak pun dapat mengapresiasinya.

Pelayanan Umum merupakan usaha museum dalam memberikan informasi secara baik kepada pengunjung. Tujuannya agar mereka mendapat kepuasan berkaitan dengan pengetahuan tentang koleksi yang dipamerkan. Pelayanan informasi yang diberikan ini erat hubungannya dengan tujuan museum sebagai pusat studi, pendidikan, dan rekreasi.

Bentuk pelayanan yang bersifat umum ini dapat diberikan melalui panduan keliling melihat pameran di museum, baik pada pameran tetap atau 
atau pameran khusus, buku pedoman/panduan pameran tetap museum, brosur/ leaflet, VCD tentang museum, dan laman website museum. Untuk hal-hal tersebut diatas museum harus mempersiapkan secara baik sarana pelayanan, khususnya tenaga pelaksana yang menguasai metode dan teknik bimbingan (pemandu).

Pelayanan yang bersifat khusus merupakan usaha museum memberikan pelayan bagi pengunjung museum bagi yang memerlukan informasi dengan tujuan tertentu, misalnya untuk penelitian atau tugas menyusun karya tulis siswa/mahasiswa. Pengunjung yang memiliki tujuan tertentu ini biasanya sudah terbiasa menggunakan museum sebagai lembaga untuk menambah pengetahuan ataupun untuk lebih mendalami koleksi yang ada di museum. Biasanya museum sudah memeiliki program-program bagi mereka khususnya bagi para siswa/ mahasiswa baik dari tingkat TK hingga perguruan tinggi.

Bentuk pelayanan yang bersifat khusus ini dapat diberikan melalui bimbingan keliling museum bagi para siswa dengan topik-topik khusus yang telah disiapkan, ceramah/workshop dengan tema-tema (topik) khusus, pemutaran film/ video, gerakan museum masuk sekolah, museum kita baik untuk siswa ataupun untuk guru, peragaan atau demonstrasi tentang penggunaan/fungsi suatu koleksi, bimbingan karya tulis, pameranpameran khusus (lebih bersifat ilmiah dan edukatif); dan sosialisasi museum kepada masyarakat. Untuk membuat dan menyiapkan bahan pelayanan di atas diperlukan kerjasama antara museum dengan huru ataupun para ahli pendidikan agar kegiatan tersebut betulbetul mencapai tujuan yang diharapkan.

\section{Museum dan Penelitian}

Sejak awal perkembangan lembaga museum tidak dapat dipisahkan dengan ilmu pengetahuan dan ciri ilmiah merupakan predikat yang melekat pada lembaga tersebut. Hal itu seiring dengan keinginan masyarakat bahwa museum adalah suatu lembaga atau pusat penelitian ilmiah yang diharapkan dapat selalu mengkomunikasikan hasil-hasil penelitiannya kepada masyarakat.

Para ahli permuseuman menyadari betapa penting melakukan kegiatan penelitian di museum untuk suksesnya fungsionalisasi museum itu sendiri. Penelitian di museum berbeda dengan penelitian di lembaga akademis pada umumnya. Penelitian di museum adalah karya bersama antara staf museum yang dapat mengarah kepada kepala museum.

Subjek penelitian di museum dapat dibagi menjadi dua.Pertama, subjek penelitian bersumber pada masalah yang berkaitan dengan koleksi museum. Hasil penelitian ini kemudian dikomunikasikan kepada masyarakat melalui penerbitan atau pameran. Kedua, subjek penelitian yang bersumber pada masalah bukan koleksi, termasuk penelitian pengunjung museum. Hasil penelitiaan ini akan digunakan untuk dasar penyusunan kebijakan dalam pengelolaan museum.

Dalam melaksanakan penelitian di museum, perlu diperhatikan tesa-tesa yang wajib dijadikan sebagai pegangan oleh para peneliti. Tesa-tesa tersebut adalah sebagai berikut setiap peneliti harus sejalan dengan visi dan misi museum masing-masing, setiap peneliti harus bersandarkan pada tugas pokok 
dan fungsi (tupoksi) museum, kepala museum harus mampu mengarahkan dan menjadi motivator bagi staf untuk melakukan penelitian, penelitian di museum harus dilakukan atas nama tim karena hasil penelitian akan dilaporkan atas nama museum. Tim peneliti dibentuk oleh Kepala Museum yang minimal terdiri dari seorang sebagai peneliti dan dua orang sebagai asisten peneliti, komposisi peneliti tersebut dapat disesuaikan dengan bentuk dan keluasan cakupan penelitian. Penelitian dapat diajukan oleh setiap staf fungsional museum dengan prosedur sebagai berikut para staf fungsional museum mengajukan proposal penelitian kepada kepala museum, kepala museum dan/atau tim penilai yang ditunjuk memberikan penilaian terhadap proposal, apabila diterima, kepala museum membentuk tim penelitian, Tim penelitian dapat melaksanakan penelitiannya dengan memperhatikan segara prosedur penelitian, apabila ditolak, kepala museum memberikan arahan dan mengembalikan proposal kepada para staf fungsional untuk diperbaiki dan diusulkan kembali. Bagi museum yang belum memiliki atau terbatasnya tenaga yang cakap untuk melakukan penelitian dapat bekerjasama dengan museum atau instansi penelitian lain yang relevan.

Penelitian koleksi museum sangat penting dilakukan oleh para kurator bidang koleksi. Bagi suatu museum upaya untuk menginformasikan koleksinya kepada publik bukanlah persoalan yang mudah. Sejumlah informasi mengenai koleksi yang akan dikomunikasikan sedapat mungkin tersedia secara maksimal. Dalam hal ini peran penelitian koleksi museum yang dilaksanakan para kurator bidang koleksi sangat penting artinya. Mereka haris menguasai betul pendekatan disiplin ilmu yang khas dan berkenaan dengan koleksi yang akan ditelitinya.

Dalam melakukan penelitian terhadap koleksi museum perlu diperhatikan sumber acuan agar hasil penelitian koleksi tersebut bersifat valid. Dalam hal ini, koleksi menempati kedudukan utama dan menjadi tumpuan perhatian selama penelitian berlangsung. Beberapa butir acuan yang patut diperhatikan, diantaranya sebagai berikut: adanya permasalahan yang menjadikan koleksi sebagai data utama penelitian, permasalahan penelitian yang disusun harus berkenaan dengan koleksi.

Koleksi merupakan hal yang pertama harus menjadi fokus perhatian, tumpuan penelitian dan bahan kajian. Jadi koleksi bukan merupakan data sekunder, adanya penelitian secara fisik terhadap koleksi (terhadap pengukuran, penggambaran, pemotretan, dan lainlain), paling tidak harus ada penelitian secara fisik terlebih dahulu terhadap koleksi, dan sudut bahan, ukuran, gaya dan lain-lain disertai dengan aktivitas pengukuran,pemotretan, penggambaran, dan hal lainnya. Jadi, penelitian koleksi lewat foto atau gambar merupakan hal yang kurang baik, kecuali apabila sangat terpaksa (sebagai data pendukung) atau koleksi dimaksud sukar diperoleh karena misalnya koleksi disimpan di museum luar negeri, Adanya pemecahan/ pembahasan masalah yang berkenaan dengan penelitian koleksi, Pemecahan atau jawaban terhadap masalah penelitian terlebih dahulu adalah pemecahan masalah-masalah yang berkaitan langsung dengan koleksi, hasil penelitian dapat memberikan penjelasan 
yang lebih luas pada koleksi yang diteliti secara mandiri, apabila terdapat koleksi yang diteliti secara khusus (mandiri) yang berkaitan dengan koleksi-koleksi lainnya.

Hasil penelitian itu harus dan mendalam tentang seluk-beluk koleksi tersebut.Tidak perlu dikaitkan dengan uraian-uraian koleksi lainnya, hasil penelitian dapat memberikan penjelasan secara lebih luas dalam konteks ilmu pengetahuan, misalnya sejarah, arkelologi, antropologi, sosiologi, dan politik. Hasil penelitian terhadap koleksi museum diharapkan juga dapat memberikan masukan yang lebih luas pada wawasan ilmu pengetahuan. Artinya, walaupun hanya bersifat penelitian terhadap koleksi suatu museum, namun hasilnya dapat disumbangkan bagi penambahan wacana kognitif (data dan asumsi) pada suatu bidang ilmu yang berkaitan dengan koleksi yang bertemakan multikulturalisme, atau lainnya, Hasil penelitian terhadap koleksi juga dapat menghasilkan suatu dukungan terhadap suatu teori yang sudah umum, misalnya tentang difusi, akulturasi, dan local genius, diharapkan adanya manfaat dalam konteks kemasakinian atau masa yang akan datang bila dilakukan penelitian terhadap koleksi. Sejalan dengan pandangan bahwa museum harus berperan dalam masyarakat masa kini dan mampu mengikuti perkembangan zaman, maka hasil penelitiannya pun mengandung bagianbagian yang dapat disumbangkan pada zaman sekarang (McClean, 1996).

\section{Alur Penelitian di Museum}

Penelitian terhadap koleksi museum secara garis besar dapat dibagi menjadi tiga jenis penelitian, yaitu pertama, suatu penelitian terhadap koleksi sepenuhnya bertujuan untuk memberikan penjelasan tentang riwayat koleksi itu sendiri. Kedua,Penelitian tentang suatu koleksi dengan tujuan untuk menguraikan peranan suatu koleksi yang lebih luasnya dalam kerangka sejarah (kesenian, politik, masyarakat, ekonomi, dan lain-lain). Ketiga, Penelitian terhadap koleksi dengan tujuan hanya sebagai data pendukung dari suatu kajian peristiwa yang pernah terjadi.

Museum juga melakukan penelitian di luar koleksi. Penelitian tersebut dilakukan oleh staf fungsional bidang edukasi, konservasi, dan preparasi. Misalnya, penelitian mengenai pengunjung museum, apresiasi masyarakat terhadap museum, konservasi, dan pengamanan museum.Penelitian-penelitian tersebut pada umumnya merupakan penelitian dasar kebijakan yang berbasis pada keinginan pengunjung. Hasil dari penelitian ini digunakan untuk dasar penyusunan kebijakan manajemen, ppetunjuk pelaksanaan tugas, serta petunjuk teknis. Berbeda dengan penelitian koleksi yang hasilnya disajikan kepada masyarakat.

Dalam melaksanakan penelitian buka koleksi perlu diperhatikan beberapa acuan agar penelitian itu shahih. Masyarakat, baik pengunjung museum maupun masyarakat di sekitar museum menempati kedudukan utama dan menjadi tumpuan perhatian selama penelitian berlangsung. Beberapa butir acuan yang patut diperhatikan, diantaranya sebagai berikut: pertama, ada permasalahan yang menjadikan kebijakan museum sebagai masalah utama penelitian. Masyarakat pengunjung museum, masyarakat disekitar museum, konservasi, dan 
pengamanan museum menjadi fokus perhatian, tumpuan penelitian, dan bahan kajian. Kedua, Pendekatan penelitian yang digunakan secara umum dapat dikelompokkan menjadi pendekatan kualitatif dan kuantitatif.Keempat,adanya pemecahan/ pembahasan masalah yang berkenaan dengan kebijakan museum yang mengacu pada kedua pendekatan keilmuan. Kelima, diharapkan muncul prediksi, saran, dan rekomendasi yang patut dijadikan bahan dalam rangka penyusunan kebijakan manajemen, petunjuk pelaksanaan tugas, dan petunjuk teknis. Keenam, diharapkan ada manfaat dalam konteks konsep pengembangan pengelolaan museum. Ketujuh, hasil penelitian diharapkan dapat memberikan masukan kepada kepala atau pengelola museum.

\section{SIMPULAN}

Keberadaan musem dalam dunia pendidikan begitu dibutuhkan, termasuk dalam pembelajaran sejarah. Baik dari level pendidikan yang peling rendah hingga tinggi. Seorang siswa dari sekolah dasar akan senang bila belajar di museum, dibandingkan di dalam kelas. Di museum mereka bisa mengamati benda peninggalan masa lampau secara langsung. Proses pembelajaran juga bisa dilaksanakan oleh pengunjung yang bukan berasal dari kalangan pendidikan. Seorang turis yang berkunjung ke museum, baginya akan menambah khasanah kekayaan mental dan intelektual untuk mengetahui masa lampau dari suatu etnis atau kelompok masyarakat. Di museum juga bisa dilaksanakan penelitian koleksi, hal ini memberikan peluang untuk menghasilkan temuan terbaru. Penelitian bagi mahasiswa, dosen, dan siapapun yang tertarik dengan museum.

Fakta dan kenyataan yang kita temukan hari ini adalah masih minimnya masyarakat untuk berkunjung ke museum. Banyak faktor yang menyebabkan minimnya orang berkunjung ke musuem, namun lambat laun museum yang ada di Indonesia sudah mulai berbenah.Sarana dan prasarana pendukung mulai diperbaiki dan bersih, sehinggan kesan museum yang kotor dan kusam selama ini bisa ditepis. Layanan pengunjungpun sudah dilakukan inovasi. Pengunjung dimanjakan dengan pemandu yang edikatif, ramah, dan profesional serta pusat informasi digital.

\section{DAFTAR PUSTAKA}

Kedding O., U. (1991). Museum dan Anak-Anak: Risalah- Risalah Tentang Pendidikan. Jakarta: Balai Pustaka

Mclean, K. (1996). Planning for People in Museum Exhibitions. Michigan: Association of Science Technology Centres.

Miles \& Huberman. (1992). Analisis Data Kualitatif. (diterjemahkan Ole: Tjetjep Rohedi Rosidi). Jakarta: Universitas Indonesia.

Moleong. (2006). Metodologi Penelitian Kualitatif. Bandung: PT Remaja Rosdakarya

Republik Indonesia. (1995). Peraturan Pemerintah Republik Indonesia Nomor 19 Tahun 1995 tentang Pemeliharaan dan Pemanfaatan Benda Cagar Budaya di Museum. Jakarta : sekertariat negara, 1995. Lembaran negara republik indonesia tahun 1995 nomor 35. 